\title{
HISTÓRIAS DE IMAGENS GUARDADAS: \\ NARRATIVAS DE NEGRITUDE, CONFLITO E RELIGIOSIDADE NA ILHA \\ DA PINTADA, PORTO ALEGRE, RS.
}

Fernanda Rechenberg ${ }^{1}$

A antropologia tem dedicado particular atenção, nas últimas décadas, ao estudo das práticas de colecionamento e das condições de objetivação do Outro, presente nos acervos fotográficos institucionais, seja em museus etnográficos, históricos, em arquivos e mesmo nas coleções não institucionalizadas, fruto de pesquisas antropológicas. As chamadas "etnografias de arquivo" se tornaram uma possibilidade de revisitar as narrativas engendradas dos museus e arquivos, frequentemente orientadas por uma consciência histórica.

Mais recentemente, o interesse em torno das fotografias vernaculares e suas diferentes modalidades de produção, colecionamento e circulação, tem se constituído como um objeto privilegiado nas pesquisas antropológicas, motivados, em muitos casos, pela incorporação dos acervos fotográficos dos interlocutores como suportes de uma narração reflexiva do tempo nos estudos de memória social.

Durante a pesquisa de doutorado, estive particularmente interessada nas imagens que escapavam ao "enquadramento da memória", o qual propunha discursos organizados em torno de acontecimentos e de grandes personagens (Pollak, 1989). Ao pesquisar a presença de homens, mulheres e crianças negras nas fotografias contidas em dois museus na cidade de Porto Alegre, de instância municipal e estadual, não era difícil perceber o "golpe de corte" espaço temporal que assinalava a exclusão de uma parcela da população nas escolhas envolvidas na formação dos acervos ${ }^{2}$.

Ao identificar a consagração de fotógrafos e grupos sociais específicos em tais acervos, percebi as ausências de imagens fortemente enraizadas nos afetos e memórias coletivas de grupos e famílias negras nestes espaços musealizados. Tanto a religiosidade afro-brasileira como os retratos de uma população urbana negra e pobre figuravam

\footnotetext{
${ }^{1}$ Universidade Federal de Alagoas, Brasil. Email: fernandarechenberg@gmail.com ORCID id: https://orcid.org/0000-0003-2793-8333

2 Essa ausência era, entretanto, paradoxal: sua presença "invisível", nas margens ou nas bordas das fotografias, é o sustentáculo de todos os retratos, monumentos, edificações que constituíam a expressão visual de uma modernização pomposamente documentada pelos fotógrafos no início do século XX em Porto Alegre.
} 
esparsamente nestes acervos, os quais eram, em grande parte, responsáveis pela conformação de uma memória visual de Porto Alegre. Não é à toa que as pesquisas com coleções fotográficas vernaculares tem se afirmado como possibilidades de compreender práticas sociais que escapam à visualidade recorrente de uma historiografia urbana.

Ao longo da pesquisa etnográfica, observei o apreço das famílias investigadas pelo aparato fotográfico e pela produção de imagens de si, como forma de documentação de uma memória individual, familiar ou de uma determinada rede ou grupo social. A descontinuidade dessas memórias que constituem formas distintas de rememorar a cidade é fundamental para compreendermos a dinâmica que configura diferentes formas de narrar e de se viver em Porto Alegre, atravessadas pelo pertencimento a categorias ora flexíveis, ora determinantes nas experiências de ser "preta", "batuqueira", "pobre”, "vileira” ou "ilhéu”.

Neste artigo, me debruço em torno do acervo fotográfico de uma de minhas principais interlocutoras na pesquisa de doutorado, Dona Leoni, mulher negra cuja narrativa de chegada na Ilha da Pintada é uma espécie de ancoradouro às reivindicações políticas de pertencimento negro a este território insular. Proponho narrar este encontro etnográfico utilizando imagens que evocam temporalidades distintas: as fotografias do acervo de Leoni e as fotografias produzidas por mim durante a pesquisa etnográfica, entre os anos de 2009 e 2010.

A Ilha da Pintada é uma das dezesseis ilhas que integram o bairro Arquipélago, pertencente ao município de Porto Alegre. Envolvido pelas águas provenientes dos rios Jacuí, Caí, Gravataí, Sinos e pelo Lago Guaíba, o ambiente deste bairro peculiar vem assumindo a feição de uma periferia urbana, apresentando em suas margens o contraste entre uma população empobrecida residente em barracos e casas sob palafitas, e as mansões e os clubes náuticos destinados ao veraneio de uma classe economicamente privilegiada. Nas margens das ilhas, o trabalho com o lixo reciclável convive com as práticas tradicionais de pescadores e barqueiros ${ }^{3}$.

A Ilha da Pintada diferencia-se das demais ilhas por constituir uma espécie de centro do Arquipélago, consolidando até a década de 1950 uma urbanidade em pequena escala que contava com serviços como cartório, posto policial, cinema, escolas e

\footnotetext{
${ }^{3}$ Compreendidas como parte de um ecossistema de significativa importância ambiental para a cidade e o estado, as ilhas integram o Parque Estadual Delta do Jacuí, investindo-se das tensões decorrentes do confronto da configuração urbano-industrial da cidade com a formulação de políticas de preservação ambiental.
} 
armazéns (Araújo, 1998). Nessa época, o único meio de transporte era o fluvial. Com a construção da ponte móvel que conecta as ilhas ao centro da cidade em 1950, o fluxo entre as ilhas diminuiu, e tais equipamentos urbanos foram desaparecendo, fortalecendo o vínculo e a dependência das ilhas ao centro de Porto Alegre. Diferentemente de outras ilhas, ocupadas por moradores de baixa ou baixíssima renda, a Pintada possui uma significativa população de classe média, residente em casas de alvenaria. A maioria destes moradores habita a parte de cima da Ilha, uma região que reúne escolas, uma praça, comércio, o posto de tratamento de água, o Centro Administrativo da Prefeitura (CAR) e a Colônia de Pescadores Z-5 ${ }^{4}$.

É ao sul da ilha, na região conhecida como Mabilde, que se localiza o Centro de Umbanda Reino de Yemanjá e Oxóssi, a terreira, lócus de práticas e tradições afroreligiosas que mobiliza uma rede de sociabilidade e vizinhança nesta parte da ilha reconhecida como de baixo. A terreira é ancorada em três fortes lideranças femininas: Leoni e suas filhas Rosi e Bia, ou nega Bia.

Foi a partir da "liderança carismática" de nega Bia que nas últimas décadas, a Ilha da Pintada entrou no cenário político de reconhecimento e de produção de visibilidade de tradições e territorialidades negras na cidade de Porto Alegre. Embora seja um território historicamente identificado com uma origem de povoamento açoriana, fazendo eco à "matriz explicativa" da fundação da cidade (Monteiro, 2006), esta rede de moradores reivindica na ilha uma identidade negra territorializada. A constituição deste "nós" coletivo acontece em um local historicamente marcado por um contexto de repressão a uma minoria de indivíduos negros que em meados do século XX passa a residir entre os já estabelecidos moradores brancos na Ilha da Pintada.

Esta mobilização de uma identidade étnica vincula-se a reivindicação de um espaço social e político de atuação, na qual um grupo se mobiliza em torno do reconhecimento de uma memória negra, apontando para a constituição de "novos patrimônios" (Jeudy, 1990) na cidade de Porto Alegre, na direção de um processo de

\footnotetext{
${ }^{4}$ Fundada em 1921, a Colônia de Pescadores Z-5 abrange toda a região do Delta do Jacuí, além de outros municípios da região sul do Estado.

${ }^{5}$ A rede social de Bia na ilha é formada por uma malha relativamente "estreita" (Bott, 1976), que caracteriza as relações dos filhos com a mãe-de-santo, mas também passa por relações cordiais e amigáveis com as lideranças pesqueiras mais tradicionais, situadas na parte de cima da ilha, com religiosos de igrejas católicas e evangélicas, e com moradores da parte de baixo da ilha que não frequentam a terreira. Na Pintada, Bia configura um território no qual é "madrinha" e "mãe" de muitos dos moradores da parte de baixo. Por outro lado, parece ultrapassar as fronteiras religiosas ao ser ativista em uma $\mathrm{ONG}$ e uma das principais representantes do bairro Arquipélago nas comissões da prefeitura municipal.
} 
“etnicização da vida urbana no Brasil” que desacomoda as hierarquias de ocupação do espaço e insere novos agentes sociais nos intrincados jogos e disputas pelo poder econômico e político (Nunes e Rocha, 2009).

Este movimento inseria-se em um cenário nacional de implementação de uma política cultural estruturada no conceito antropológico de cultura e na reparação de dívidas históricas com as populações negras e indígenas, a qual fomentou o desenvolvimento de ações políticas de reconhecimento e valorização das memórias coletivas de seus grupos étnicos formadores ${ }^{6}$. No âmbito estadual e municipal, também era perceptível à época da pesquisa, que tais políticas culturais discursavam a favor de uma reinscrição da população negra na identidade gaúcha e porto-alegrense, reunida nos termos de um "povo" que compartilha distintas práticas e identidades étnicas e culturais.

Neste contexto surgiu o projeto intitulado "A história do negro na Ilha da Pintada", do qual participei ministrando oficinas de fotografia a jovens e crianças. De proporções e recursos modestos, o projeto foi realizado entre os anos de 2009 e 2010 através de um programa vinculado à Secretaria Municipal de Cultura ${ }^{7}$, com o objetivo de dar visibilidade à presença negra na ilha. Através de "oficinas de expressão artística", o projeto trazia uma proposta colaborativa de produção de um livro com as memórias dos habitantes negros na Ilha da Pintada. As aulas de fotografia, sob minha responsabilidade, tinham como objetivo instrumentalizar os alunos na técnica fotográfica, estimulando a documentação fotográfica de seu próprio ambiente em várias dimensões: suas casas e famílias, seus amigos, o cotidiano e as paisagens da Ilha, as festas e eventos que participavam além de retratos de si próprios. Foi por meio do "mote fotográfico", construindo uma relação com os jovens e suas famílias, que desenvolvi a pesquisa etnográfica junto à rede de vizinhança e sociabilidade que entrelaça família de sangue e de santo em torno da terreira.

\footnotetext{
${ }^{6} \mathrm{O}$ ano de 2003, com a posse de Luiz Inácio Lula da Silva constitui o marco desta priorização de recursos e ações no campo das políticas públicas destinadas à cultura no Brasil.

7 Em Porto Alegre, a partir do ano de 1994, a administração municipal desenvolveu ações voltadas a uma política cultural "descentralizada". O programa denominado Descentralização da Cultura, vinculado à Secretaria Municipal da Cultura (SMC/PMPA), havia sido criado com o intuito de proporcionar o "exercício pleno da cidadania também na área cultural" (Heberle, 2011), fazendo eco a um movimento mais amplo do debate em torno dos direitos culturais. Esta política cultural municipal atuava com base no reconhecimento de uma desigualdade de acesso e produção de bens culturais a qual estava associada à distribuição espacial da cidade, reproduzindo os padrões de segregação urbana.
} 


\section{Das fotografias que se abrem: memórias de Leoni}

Dispostas em cronologias a serem narradas nos álbuns, emolduradas em quadros, porta-retratos ou na versão moderna dos murais, escondidas em pequenos envelopes no interior de livros pouco manuseados ou em caixas dentro de armários, as fotografias acumulam experiências, sentimentos e afetos sempre renovados no gesto que se dedica a escavar estas imagens. Nas experiências cotidianas de lembrar e esquecer, os "jogos da memória" (Eckert e Rocha, 2005), as fotografias nos convidam a uma “apropriação afetiva do tempo" (Bucci, 2008).

Como nos ensina Gaston Bachelard (1994), não se pode reviver o passado sem o encadear em um tema afetivo presente. Nas emoções provocadas pelo mote fotográfico, a constituição de uma imagem do presente, necessariamente levava a uma reflexão sobre os tempos vividos, tempos de experiências individuais e coletivas nos laços de amizade, família e vizinhança, tempos nos quais os sujeitos se reencontravam na poeira de seus acontecimentos pessoais (Bachelard, 1994).

Como bem assinalou José de Souza Martins, “a prática de colocar fotografias em caixas de sapatos ou em gavetas é uma necessidade não só de guardar, mas de esquecer temporariamente" (Martins, 2008: 45). Este esquecer sabendo que está lá, revela uma verdadeira "inteligência do esconderijo", uma "necessidade de segredos" do homem sonhador (Bachelard, 1996: 94). Os cofres, as gavetas, as fechaduras e os armários, são imagens que contêm as reservas dos devaneios da intimidade, onde o homem encerra ou dissimula seus segredos. Mas todos estes esconderijos, Bachelard faz questão de nos lembrar, são “objetos que se abrem”.

Quando retiradas das caixas e gavetas, as fotografias convocam a esta apropriação da intimidade: não mais engavetadas, são colocadas à luz, tira-se a poeira de sua superfície, são olhadas com cuidado. Algumas destas imagens não serão vistas, ou então serão recusadas, permanecendo no escuro de seus esconderijos, dispersos em meio a uma poeira de instantes.Outras serão escolhidas, olhadas, comentadas, narradas, compartilhadas, apoiando a fabricação de uma continuidade temporal e se tornando solidárias no encadeamento do tempo de uma existência. 
Nas casas que visitei, nunca tive fácil acesso aos esconderijos que guardavam as fotografias. Podia observar as imagens emolduradas e disponíveis ao olhar do visitante nos espaços mais públicos das casas, ou então, as fotografias organizadas nos álbuns em narrativas passíveis de serem compartilhadas. As fotografias que eram guardadas em esconderijos sempre chegavam em minhas mãos após cuidadosos exames e seleções, ou depois de longos meses de convivência, como foi o caso de Leoni.

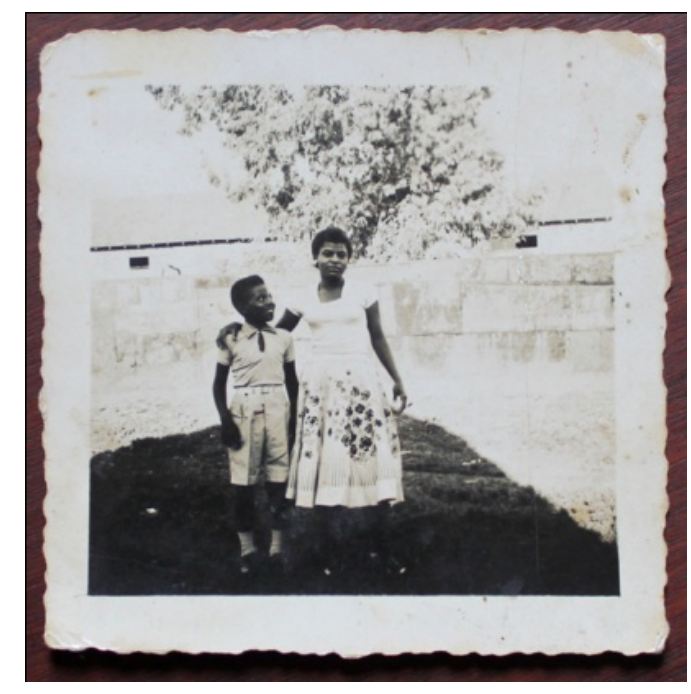

À época de pesquisa de campo, Leoni, ou Lia, como é chamada pelas filhas, trabalhava na casa de um homem de meia idade, fazendo o almoço e arrumando a cozinha. Saía pela manhã em direção ao centro da cidade, e retornava à Ilha por volta das 15 horas, diariamente, percorrendo de ônibus o caminho de águas, pontes e ilhas que liga a Pintada ao centro de Porto Alegre. O restante do tempo era dedicado às atividades relacionadas à terreira, à escola de samba, e ao cotidiano compartilhado por vizinhos, família de sangue e de santo, e também por terreiras e grupos de mulheres em outras localidades da cidade e fora dela. Era comum Dona Leoni passar noites em claro cozinhando para festas e rituais na terreira, embora reclamasse com frequência da quantidade de afazeres, se dizendo cansada. Filha de Oxóssi, Exu Tranca Rua, Mãe Maria e outras passagens que a Umbanda lhe proporcionava, Leoni reunia filhos, netos, bisnetos e toda a família de santo em torno de sua personalidade forte e explosiva, conhecedora de uma tradição religiosa e dos tempos antigos da ilha.

Sua condição de "narradora", provocada pela presença de um grupo de pessoas dispostas a escutar suas memórias e investigar "a história do negro na Ilha da Pintada", implicava em um mergulho nos tempos difíceis nos quais havia chegado na Ilha da Pintada, há mais de 50 anos. As fotografias eram um "ponto de partida" para uma 
“viagem" permeada por sentimentos e emoções, em que a memória era convidada a se colocar (Barros, 1989). Entrelaçando sua narrativa com as fotografias de seu acervo particular, proponho narrar as memórias da chegada de Leoni na ilha e os primeiros e sofridos tempos, os quais constituem o esteio para o desenrolar de um conjunto de práticas e narrativas que amparam a memória desta família negra na Ilha da Pintada.

Leoni chegou à Ilha da Pintada nos anos de 1950, acompanhada de seu pai, admitido para trabalhar no Estaleiro Mabilde. Depois de passar a infância na cidade de Charqueadas, crescendo em meio a parentes e amigos, Leoni conheceu, na ilha, uma marca que seu corpo nunca mais esqueceria. Na Ilha da Pintada, à época um território predominantemente habitado por descendentes de europeus, os negros recém-chegados reuniam olhares de espanto. Nas lembranças de um passeio na praça com seu namorado, um rapaz negro vindo de Charqueadas, podia escutar as pessoas chamando umas às outras nas casas para ver os corvos de mãos dadas. Corvo, anu, macaco, urubu.

Atribuir a um corpo humano as metáforas de certos animais mostra a conformação de um "estigma" no enquadramento de características não previstas neste encontro com a diferença do Outro $^{8}$. As comparações animalescas que eram acionadas pelos habitantes da ilha no enfrentamento da diferença, recorriam a metáforas que criavam estereótipos a partir de características e hábitos de tais animais. $\mathrm{O}$ anu, por exemplo, é um pássaro preto que se caracteriza por viver sempre em bandos, ocupando territórios coletivos durante todo o ano. A escolha de tais animais, portanto, não falava apenas de uma negatividade atribuída à suas características quando associadas à condição humana, mas denunciava reações diante de fatos presentes, como a chegada destes migrantes na ilha. Tais comparações não eram novidade, mas refletiam uma longa história de estigmatizações do indivíduo negro na sociedade brasileira e gaúcha ${ }^{9}$.

A rua era o principal espaço desses confrontos: palco da visibilidade e do achaque públicos. A jovem Leoni evitava sair às ruas. Para contornar o falatório na Ilha da Pintada, casou-se em casa e não frequentou a escola. Toda a trajetória de Leoni é fortemente marcada por estas lembranças da juventude. As cenas do preconceito e

\footnotetext{
${ }^{8}$ Segundo Erving Goffman, a atribuição do estigma acaba por construir uma teoria, uma ideologia capaz de "explicar a sua inferioridade e dar conta do perigo que ela representa, racionalizando algumas vezes uma animosidade baseada em outras diferenças, tais como a classe social" (Goffman, 1982:15).

9 Augusto Meyer, em "Cancioneiro Gaúcho", assim descreve o pássaro na poesia "O Anu": 1/O anu é pássaro preto/Passarinho de verão/Quando canta à meia-noite/Ó que dor no coração. 2/ E se tu, anu, soubesses/Quanto custa um bem-querer/Ó pássaro, não cantarias Às horas do amanhecer. 3/O anu é pássaro preto/Pássaro do bico rombudo/Foi praga que Deus deixou/Todo negro ser beiçudo (Meyer, 1959)
} 
racismo que viveu voltavam à tona com frequência em nossos encontros. Embora ela usasse um tom jocoso para falar desta época, eu percebia o caráter marcante dessa experiência em sua biografia e na valorização de uma identidade negra que era transmitida a seus filhos. As imagens narradas mostravam a força de uma cisão entre os moradores antigos, ilhéus, brancos e pescadores, e os moradores novos, os negros, os lombo sujo, como eram chamados pelas crianças da ilha os trabalhadores oriundos das carvoarias de cidades como Triunfo, Charqueadas e São Jerônimo. Diferenças de raça, etnia, trabalho, tradições.

Apesar de não ter frequentado a educação formal na Ilha da Pintada, Leoni buscou alternativas que proporcionassem uma formação técnica e também a inserção em redes de sociabilidade femininas. $\mathrm{O}$ fato de Leoni ter abandonado os estudos estava associado tanto a um conjunto de experiências vivenciadas como "estigma" que ela buscava evitar, como a um contexto mais amplo de constrangimentos na formação escolar de jovens negros. Se para Leoni, ir à escola exigiria a circulação diária no espaço das ruas e o enfrentamento de relações conflituosas que ela antevia estabelecer com as professoras e colegas brancos, informando sobre a dimensão cotidiana que dificultava a formação intelectual de jovens negros, também elucida um contexto de políticas públicas as quais elegiam a educação como uma nova bandeira científica e um campo de ação social, imbuído de uma devida dissimulação do debate sobre a raça, responsável por uma espécie de branqueamento moral e por uma busca pela reversão do quadro de "degeneração racial" que se julgava comprometer o futuro da nação ${ }^{10}$.

\footnotetext{
${ }^{10}$ O livro de Jerry Dávila (2006) sobre o trabalho dos reformadores educacionais no Rio de Janeiro entre 1917 e 1945 indaga a partir de fotografias dos quadros educacionais de escolas sobre o desaparecimento dos professores de cor, desvendando um projeto deliberado de se forjar uma identidade para os educadores da cidade, os quais deveriam ser preferencialmente brancos e do sexo feminino. As fotografias de Augusto Malta analisadas pelo autor mostram um corpo considerável de professores afrodescendentes nas primeiras décadas do século $\mathrm{XX}$, contrastando com a quase ausência de afrodescendentes ao final das décadas de 1930 e 1940. Nesta política ideológica que associava a branquitude às virtudes da modernidade triunfante, os alunos negros reunidos em classes para alunos repetentes eram "a prova científica do atraso e da degeneração dos afrodescendentes” (Dávila, 2006:195).
} 

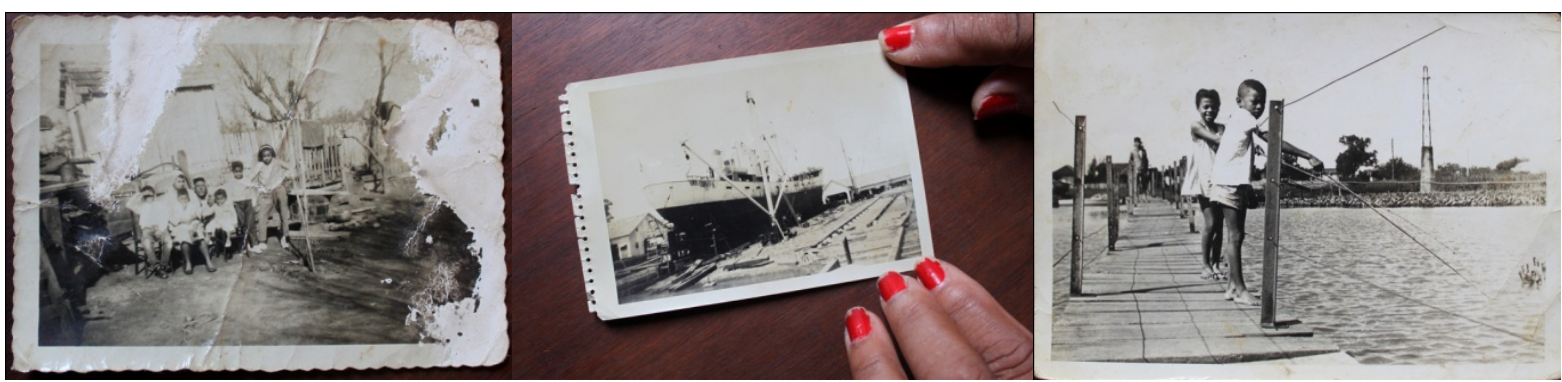

Fotografias do acervo de Leoni

Navegando em imagens de historiadores e cronistas, vemos que o recorte temporal narrado por Dona Leoni traz nas "dobras" um tempo anterior de intensa sociabilidade negra na ilha. A denominação de outras ilhas do Arquipélago e o relato de antigos moradores dá indícios de que o território do Delta fosse refúgio dos escravos fugidios. A Ilha das Flores, por exemplo, era chamada Ilha da Maria Monjolla, em referência a uma nação africana, e posteriormente Ilha do Quilombo, em meados e fins do século XIX. A Ilha da Maria Conga é até hoje assim chamada, em referência ao nome de uma mulher negra muito bonita e estimada que lá residia (Porto Alegre, 1995). O fato de o primeiro ciclo de produção econômica das charqueadas no Rio Grande do Sul ter se desenvolvido às margens dos rios São Gonçalo (município de Pelotas) e Jacuí (municípios de São Jerônimo e Charqueadas) facilitou a circulação da população escravizada pelos caminhos de água que levavam ao Delta. O transporte fluvial das mercadorias era realizado principalmente por homens escravizados, "negros remadores de gôndolas do rio Jacuí", imagens trazidas por viajantes como Arsène Isabelle, em 1833. O registro histórico mais importante referente à presença de negros no Arquipélago é o registro da compra de terras na Ilha do Quilombo pela escrava forra Mariana Maria, em 1810, um fato excepcional para a sociedade escravocrata da época. Outro registro datado de 1844 é o anúncio publicado em jornal referente à fuga de José Marques da Silva Jr., o qual foi visto "andando pelas ilhas tocando viola em fandangos". Estima-se que tais fandangos eram compostos por outros escravos fugidios, que já habitariam as ilhas (Porto Alegre, 1995).

Em outros tempos, a rota segue os caminhos do rio. Em meados do século XX os negros que antes cumpriam um trabalho escravo nas charqueadas, agora enfrentavam o pesado trabalho nas carvoarias e estaleiros. Cem anos depois da fuga destes homens e mulheres escravizados, Dona Leoni chega à Ilha da Pintada navegando pelas águas do Delta: 
Leoni: Eu me mudei pra cá dia 24 de agosto de 1956. Era o dia do aniversário do meu pai, a gente veio em duas familia. A gente vinha, eles botavam as mudança da gente numa chata, chata que eles dizem, naquele tempo era o que carregava o carvão, né. Então eles colocavam as mudanças da gente e depois um braço a vapor puxava. Me lembro que a gente viajou a nooooite toda.

Situada às margens do rio Jacuí, a cidade de Charqueadas se tornava, em meados da década de 50, o novo pólo carbonífero da região. A pesquisa da antropóloga Cornelia Eckert (1985) sobre as condições de vida dos mineiros de carvão em Charqueadas mostra que o município de Arroio dos Ratos, que concentrava a exploração de carvão no Rio Grande do Sul desde o final do século XIX, sofreu um declínio na década de 50 devido à concorrência de outras fontes de energia e ao decréscimo na produção, gerando um ciclo de desarticulação da comunidade mineira e a consequente emigração desta mão de obra para a capital e seus arredores. Anos depois, foi inaugurado um poço de extração em Charqueadas, transformando a cidade em um porto escoador da produção carbonífera (Eckert, 1985: 156-157).

Os estudos do Centro de Pesquisa Histórica da Prefeitura de Porto Alegre (1995) sugerem que a intensificação da presença do negro na Ilha da Pintada data do século $\mathrm{XX}$, e está principalmente relacionada aos processos migratórios de trabalhadores oriundos de cidades próximas. Isso porque além da tradição pesqueira, a ilha abriga um importante estaleiro, que atraía operários da região da bacia carbonífera do Estado. $\mathrm{O}$ Estaleiro Mabilde já era um dos maiores do sul do Brasil quando se instalou na ilha, em 1914. A empresa construiu casas para seus trabalhadores, escola para seus filhos e armazéns de "secos e molhados" para atender ao seu abastecimento. A partir de 1943, quando o controle da administração do Estaleiro passou para o Consórcio Administrativo das Empresas de Mineração $(\mathrm{CADEM})^{11}$, acontece uma nova movimentação na chegada de operários na ilha em razão da vinda de um número expressivo de trabalhadores negros vindos da região carbonífera do Estado (Porto Alegre, 1995), de municípios como Arroio dos Ratos e Charqueadas ${ }^{12}$.

\footnotetext{
${ }^{11}$ Consórcio decorrente da união de duas companhias de extração: a Companhia São Jerônimo e a Companhia Carbonífera Rio-Grandense, em 1936.

${ }^{12}$ Cornelia Eckert (1985) mostra que o trabalho nas minas era predominantemente realizado por uma mão de obra estrangeira, mineiros imigrantes europeus, os quais enfrentavam as difíceis condições de um trabalho bruto e arriscado. O negro ingressaria neste trabalho na chamada "época de ouro" da exploração carbonífera, durante a II Guerra Mundial. Na fala de um ex-vereador local, reproduzida pela autora, este afirma que o pelo duro, o gaúcho e o negro participariam de uma terceira etapa de formação da "brava
} 
A antropóloga Susana Araújo (1998) descreve que estes trabalhadores negros, vindos da região carbonífera, sempre tiveram uma aceitação "parcial" entre os moradores mais antigos da Ilha na Pintada. Segundo a autora, que era também moradora da ilha, a chegada desses trabalhadores causou muitos comentários na época entre os ilhéus, predominando até hoje a narrativa de que não existia negros na Pintada, com exceção do Mabilde, que era considerado pelos ilhéus uma espécie de bairro à parte.

Este estigma conferido aos moradores negros que passavam a habitar o Mabilde explica as boas relações tecidas entre estes moradores e as famílias que já habitavam a Mauá, situada no entorno do estaleiro. À época da chegada de Leoni na ilha, a Mauá tinha poucos moradores e sua área alagadiça era usada para a criação de vacas. Entre estes moradores mais distantes do núcleo urbanizado da ilha, Leoni fez amizades com famílias brancas e disse sentir o preconceito de cor muito discretamente. Ao contar um episódio na festa de seu casamento, Leoni mostra que nas relações entre brancos e negros nas proximidades do estaleiro, o preconceito era suavizado, embora não estivesse ausente:

Leoni: Preconceito era cá pra cima. Ali não, porque no meu casamento mesmo a dona Lolinha foi, já é morta... Ajudou bastante no casamento, só que na hora da festa ela deu uma rateada, né: ah, hoje os branco vão ter que dançar junto com os negro!

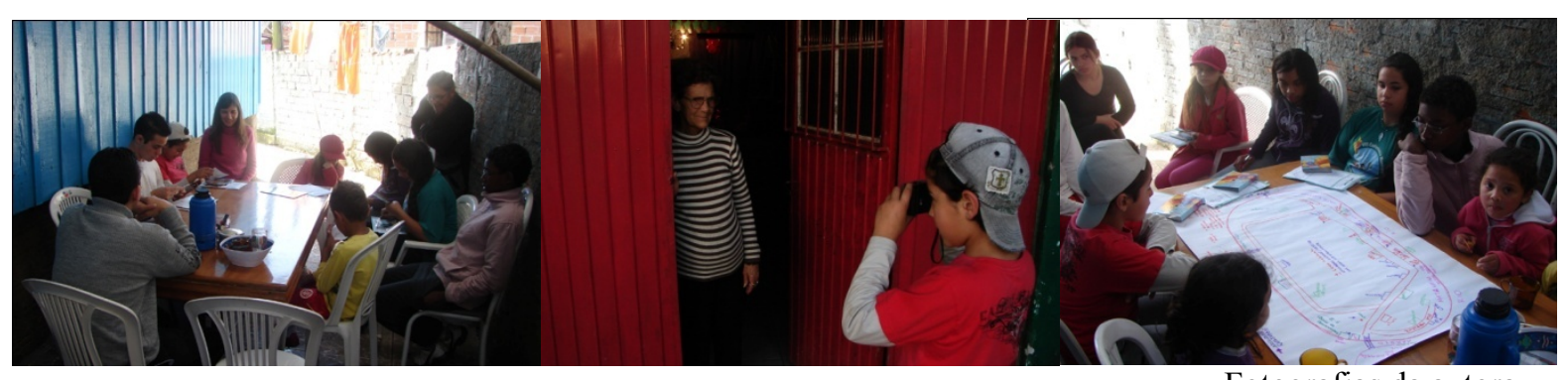

Fotografias da autora

\section{A ilha vista de baixo}

Foram os jovens alunos das oficinas que ao desenharem um mapa da Ilha primeiro chamaram atenção para a separação entre duas ilhas simbolicamente traçadas:

raça mineira", complementando o contingente de trabalhadores descendentes de ingleses, espanhóis, poloneses, austríacos, russos, alemães e italianos (Eckert, 1985:143). 
a parte de cima, onde predominam as habitações de classe média e também um pequeno centro em torno da Colônia de Pescadores Z-5, e a parte de baixo, conhecida também por Mabilde, menos urbanizada e caracterizada por uma população de classe baixa, onde esses jovens residiam.

O desenho de um "mapa mental" nos ajudou a compreender a Ilha da Pintada como um "lugar praticado", configurado pelas "práticas de espaço" de seus moradores (Certeau, 1994). Desenhar a ilha na perspectiva das "narrações cotidianas" destes jovens nos permitia inscrever essa "série discursiva de operações" que caracteriza o itinerário no mapa, cujo olhar demasiadamente distanciado acaba por produzir uma "descrição redutora totalizante das observações" (Certeau, 1994:204).

No decorrer da pesquisa, essa divisão foi se revelando uma categoria êmica que cindia e vinculava estes dois territórios na ilha. Tal designação, como já sinalizou o antropólogo Roberto DaMatta (1997), pouco tem a ver com altitudes topograficamente assinaladas, mas revelam categorias que distinguem regiões sociais convencionais e locais, onde o "baixo" frequentemente designa regiões pobres e periféricas. A parte de baixo, associada aos brejos, às regiões alagadiças e aos locais liminares, "onde a presença conjunta da terra e da água marca um espaço físico confuso e necessariamente ambíguo" (DaMatta, 1997:45), corrobora à estigmatização destes moradores instalados em uma "região moral" investida de um código moral divergente (Park, 1987), ainda que, de um ponto de vista topográfico, tanto a parte de cima, quanto a parte de baixo fossem ambientes alagadiços e suscetíveis às inundações.

À luz da pesquisa de Norbert Elias e John Scotson (2000) compreendemos o preconceito relatado por Dona Leoni como um elemento integrante de uma configuração, que reúne questões de classe social, ascendência étnica, valores morais e religiosos e a própria antiguidade de moradia no local ${ }^{13}$. Justamente por ser a ilha um "lugar de reconhecimento", "possuído" por seus moradores (Mayol, 1996), as pessoas são identificadas por sua localização em uma rede de relações, como o "sobrinho do fulano", "irmão do sicrano", "mulher do beltrano", mas também por estereótipos que refletem condições de classe e pertenças étnicas e religiosas, onde se pode ser nego, anu, batuqueiro, beata, maconheiro ou crente. Neste contexto, a presença dos

${ }^{13}$ Para Elias, a oposição que caracteriza um conflito entre estabelecidos e outsiders pode assumir diferentes rótulos. Segundo afirma o autor, "quando os migrantes têm a cor da pele e outras características físicas hereditárias diferentes das dos moradores mais antigos, os problemas criados por suas formações habitacionais e por seu relacionamento com os habitantes dos bairros mais antigos costumam ser discutidos sob o rótulo de "problemas raciais" (2000:174). 
moradores negros na parte de baixo e a expressão de suas tradições religiosas reforçavam uma aceitação parcial por parte dos moradores da parte de cima, ligados predominantemente a uma tradição religiosa católica.

O pensamento de Georg Simmel sobre as formas da vida social no mundo contemporâneo aponta para a natureza do conflito como constitutivo das relações sociais, na medida em que compreende a sociedade como resultado de interações positivas e negativas, onde tanto a unidade como a discordância são formas de associação.

Para o antropólogo Gilberto Velho, na linha das reflexões simmelianas, tais diferenças são simultaneamente constitutivas da base da vida social e fonte permanente de tensão e conflito desencadeados no processo de negociação da realidade em um sistema de interações sociais sempre heterogêneo (Velho, 2008).

Nesta perspectiva, o conflito conduz a uma forma de coesão social na qual o laço social é reafirmado e a construção de uma memória diante do conflito conduz tanto ao reforço nos sentimentos de pertencimento à ilha quanto na construção de fronteiras socioculturais. A memória traumática narrada por Dona Leoni e a tensão permanente relatada por estes habitantes entre os moradores da parte de cima e da parte de baixo da ilha, inscrevem neste território um jogo conflitual permeado de adesões e evitações a diferentes grupos e espaços na Ilha da Pintada. Assim como as práticas e interações destes moradores tinham que ser cotidianamente cotejadas na manutenção dos laços sociais, também o espaço da memória era habitado de lembranças revisitadas e negociadas no âmbito da diferença.

A memória e as narrações cotidianas destes moradores nos mostravam que os lugares eram investidos de tradições, demarcando fronteiras sociais e promovendo experiências de adesão e evitação ancoradas na memória de uma rede social e familiar, na qual as imagens rememoradas sustentavam as narrativas de preconceito e cisão na Ilha.

A Colônia de Pescadores Z-5, por exemplo, era frequentemente apresentada como um espaço pouco permeável, representativo de uma tradição da qual a família de Leoni não se reconhecia, e portanto, encontrava-se excluída. À luz da fotografia que retratava um concurso de fantasias na Z-5, no qual a filha de Bia havia participado, Rosi e Leoni comentaram: 
Rosi: Isso aqui era um desfile no Z-5, de originalidade de fantasias, e a Bia montou essa fantasia pra Aretusa, que tinha o nome de "Tributo ao Mar". Toda de pérolas, com concha... e aqui é ela desfilando a Aretusa tinha aqui provavelmente uns 10 anos.

Leoni: E a Aretusa não ganhou prêmio nenhum, primeiro lugar tirou um guri que o pai tinha que andar com ele no colo, vestido da estátua do Laçador...

Rosi: Com o guri no colo! Ah, fala sério! Ai a gente foi se desgostando dessas coisas, assim, sabe... é, porque no fim a gente fazia as coisas, e ia pra concursos, e...

Leoni: Mas é, aquela coisa, tinha um pouquinho de discriminação, agora não...

A Yemanjá negra, simbolizando a força das águas, a fertilidade, a tradição afrobrasileira. O Laçador na figura de um menino, imagem vir-a-ser do gaúcho idealizado. Quem ganharia esse concurso? Anos mais tarde, Aretusa seria a modelo principal do catálogo do grupo de artesanato Artescamas, sediado na Colônia de Pescadores Z-5, que produz joias a partir das escamas dos peixes da região.

Outra fotografia, que retratava Bia e seu irmão Belmiro dançando em uma festa na escola vestidos de "gaúcho" e "prenda" entre os colegas que não faziam uso de tal vestimenta, também provocou o comentário irônico de Rosi:

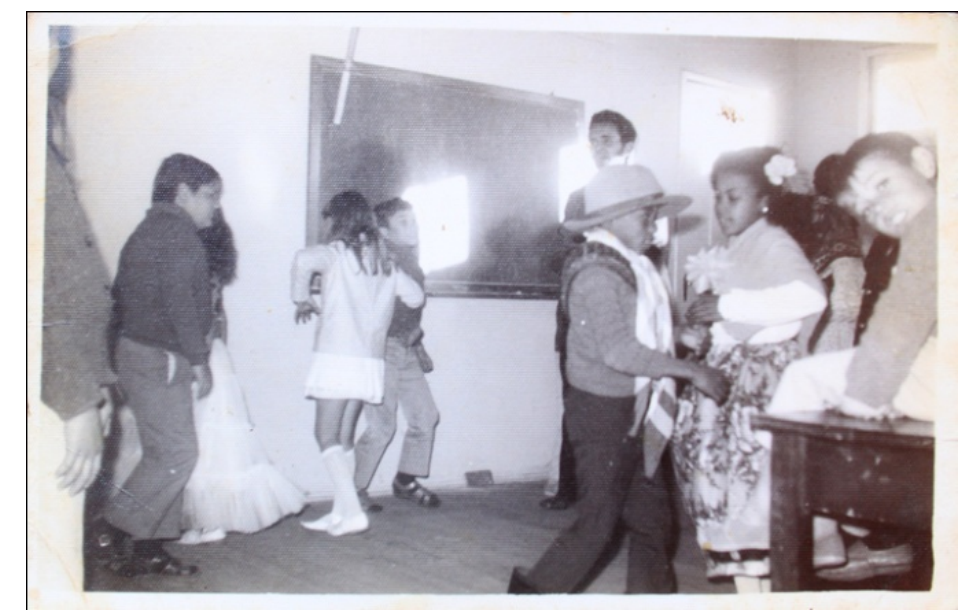

Rosi: Ih, aqui a minha irmã, com meu falecido irmão, falecido Belmiro e aqui é a Bia, dançando "oi bota aqui oi bota ali o seu pezinho...". E a Lia [Leoni] se prestava! [risos]

Leoni: Ah, não, a gente sempre teve isso, e acho que é por isso que a Bia assim, e se eu não tinha as coisa direito eu enjambrava pras criança, eu ajeitava, eu sempre incentivei assim...

F: E participavam das festas...

Leoni: Participava, apesar de chamarem de macaco, de anu, ai que eu tenho uma raiva, [risos], mas eu vou! 
Ambos os diálogos nos mostram as fronteiras que vinculam e separam estas distintas tradições. Se na época em que os filhos de Leoni eram pequenos, as expressões de uma cultura negra como a Umbanda tinham que ser praticadas às escondidas, era nos espaços públicos e institucionais de aprendizado, como a escola, que se aprendia a ser gaúcho ${ }^{14}$. A fotografia nos mostra que fora do espaço doméstico, Leoni buscava integrar os filhos nesta cultura gaúcha e pesqueira, participando de diferentes espaços de sociabilidade na ilha. Caso bem diferente é o da geração seguinte, quando suas netas e netos ganham projeção justamente na valorização das expressões afro-brasileiras, como foi o caso de Aretusa, neta de Leoni. Ambos os diálogos nos mostram a tensão entre dois "conjuntos imaginários", prenhes de símbolos, lendas e mitos (DURAND, 1998b), em que um se institucionaliza, tornando-se oficial e sendo ensinado nas escolas, e o outro permanece escondido, às margens, "selvagem". A marginalidade, entretanto, não existe em essência, nem é uma condição definitiva. Nas palavras de Gilbert Durand (1998b), o marginalizado se potencializa no lugar das margens, enquanto a linguagem social institucionalizada em verdades perde sua pregnância simbólica. O excluído de ontem torna-se o dominante de hoje.

O relato de uma volta por cima foi a primeira narrativa que escutei de Bia, ao iniciar o trabalho na ilha. Em um momento formal, em que estavam presentes moradores da ilha, o grupo de oficineiros e funcionários da prefeitura para a apresentação do projeto, escutamos Dona Leoni falar do preconceito racial sofrido em sua chegada na ilha. Depois de ouvir a fala de sua mãe, Bia contou que deu a volta nesse preconceito mostrando aos brancos algo que eles não tinham: a dança. $\mathrm{Na}$ época em que o movimento Black Power ${ }^{15}$ ganhava espaço na cidade e o grupo norteamericano "Jackson 5" tocava nas rádios comerciais, Bia e seus amigos paravam na porta dos bailes na Z-5 e dançavam na rua, porque os negrinhos lá de baixo não podiam entrar. Os brancos paravam para olhar e queriam aprender: não sabiam mexer o corpo

\footnotetext{
${ }^{14}$ Nas escolas do Rio Grande do Sul é frequente o aprendizado das tradições gaúchas, seja no estudo curricular em disciplinas como história e literatura, seja nas atividades extraclasse. Diversas escolas da rede pública e particular possuem grupos de CTG (Centro de Tradições Gaúchas), iniciando os alunos nas vestimentas e danças que caracterizam a cultura gaúcha. Sobre o tema ler a pesquisa de OLIVEN (2006) e MACIEL, Maria Eunice. Tradição e tradicionalismo no Rio Grande do Sul. In: HUMANAS, Revista do Instituto de Filosofia e Ciências Humanas. Porto Alegre, Vol. 22, n. 1/2 (1999).

${ }^{15}$ A partir da década de 1970, o sul do Brasil sentiu as influências de um movimento Black Power (Poder Negro) que se organizava em âmbito internacional, mas principalmente nos Estados Unidos. Em Porto Alegre, os frequentes encontros de uma sociabilidade negra no centro da cidade e a criação de movimentos negros locais criaram uma nova ordem estética na cidade, consolidando o "estilo chamado Black Power e suas consequências sociais e políticas" (Bittencourt Jr, 1996; López, 2009).
} 
daquela maneira. A dança, que era praticada apenas na parte de baixo da ilha, na juventude de Leoni, volta como "potência" na geração de Bia.

As celebrações dos casamentos destas três mulheres são elucidativas da dinamização desta potência. O segundo casamento de Bia, ocorrido em 2009 foi uma cerimônia afro, em que as roupas, a decoração e a condução do ritual foram pensadas segundo um imaginário associado ao continente africano. Muito diferente do casamento de sua mãe Leoni, que pagou para um padre católico para que este realizasse a cerimônia em sua casa, mantendo uma certa distância dos olhares e comentários, o casamento de Bia teve lugar no Centro de Tradições Gaúchas (CTG), situado na parte de cima da Ilha da Pintada. Anos antes, o primeiro casamento de Bia também havia sido realizado em casa, mas em uma cerimônia sem a presença de dirigentes católicos, recebendo a bênção de sua mãe de santo e de sua mãe de sangue.

Rosi, por sua vez, celebrou sua terceira união em um casamento de umbanda. Foi uma cerimônia pequena, realizada apenas para os filhos da casa na própria terreira, mas marcada pela presença de todos os elementos de distinção étnica praticados pelo grupo, como os orixás, o maculelê, os cantos e as danças, os tambores. Segundo me contou Rosi, os convites para a festa foram disputados pela vizinhança, mas ela restringiu os convidados ao povo de santo da casa, reafirmando um marcador religioso.

Os casamentos destas três mulheres nos mostram formas diferenciadas, em distintos momentos históricos, nas quais os valores relacionados a uma negritude se tornam cada vez mais expostos na ilha, atuando inclusive como um fator de distinção. Tais "fronteiras étnicas" são associadas a um conjunto de práticas e tradições (Barth, 1998), as quais mantêm uma distintividade do grupo ligada a certos marcadores étnicos, mas também permeáveis e inseridas na complexidade de relações e expressões identitárias que define fronteiras simbólicas no contexto das sociedades complexas (Velho, 2003; 2008). 
Histórias de imagens guardadas: narrativas de negritude, conflito e religiosidade...
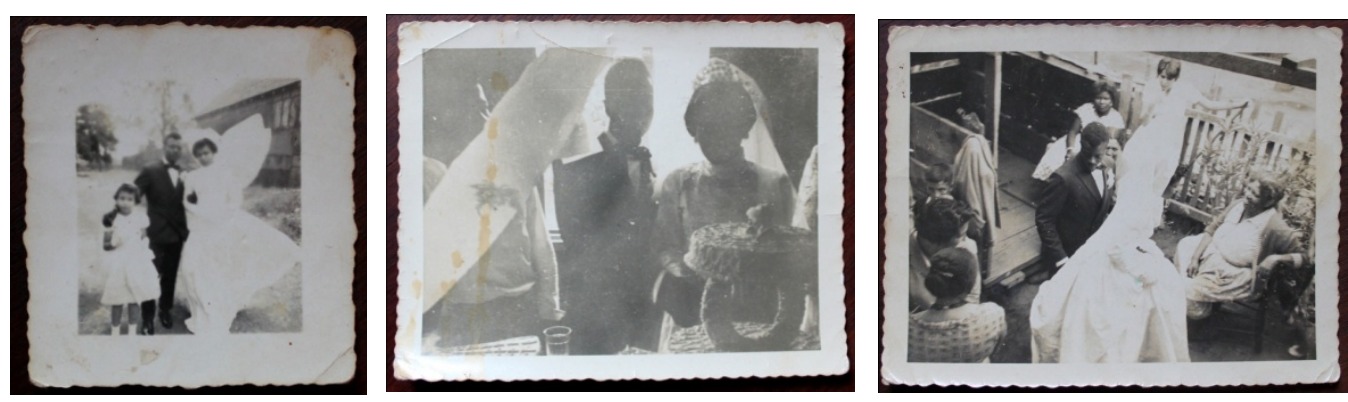

Fotografias do acervo de Leoni
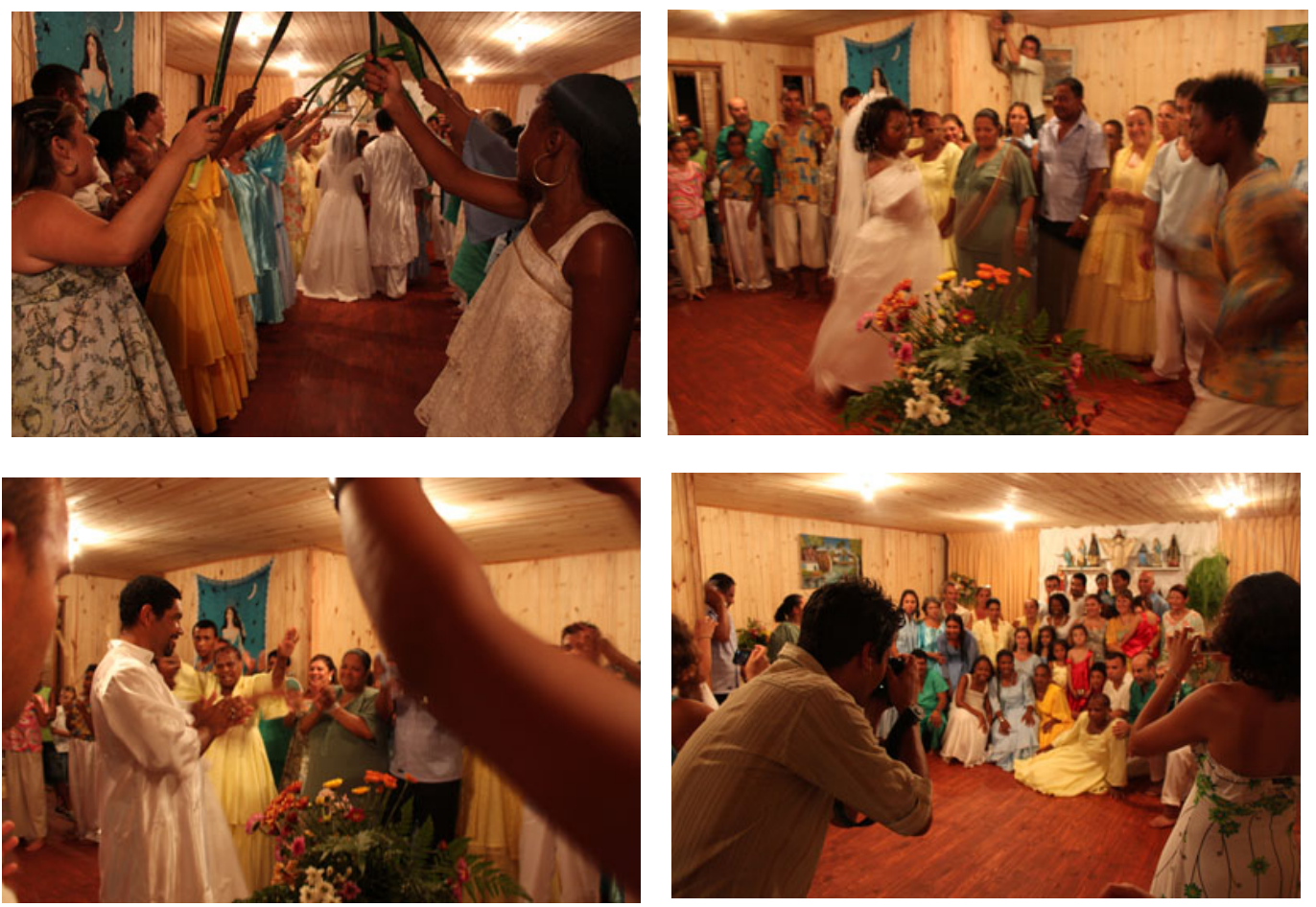

Fotografias da autora 
A participação no CTG e nas comemorações e homenagens à imagem um tanto idealizada do gaúcho, fazia convergir símbolos cujas tradições eram cotidianamente negociadas nestas interações sociais na ilha. Se era possível vestir-se de prenda e receber o título de " 1 a prenda adulta", também se podia usar roupas de Umbanda e fazer apresentações públicas no palco do CTG, no jogo conflitual de memórias que fazem convergir uma tradição "afro-gaúcha", como mostram as duas fotografias do acervo de Leoni.
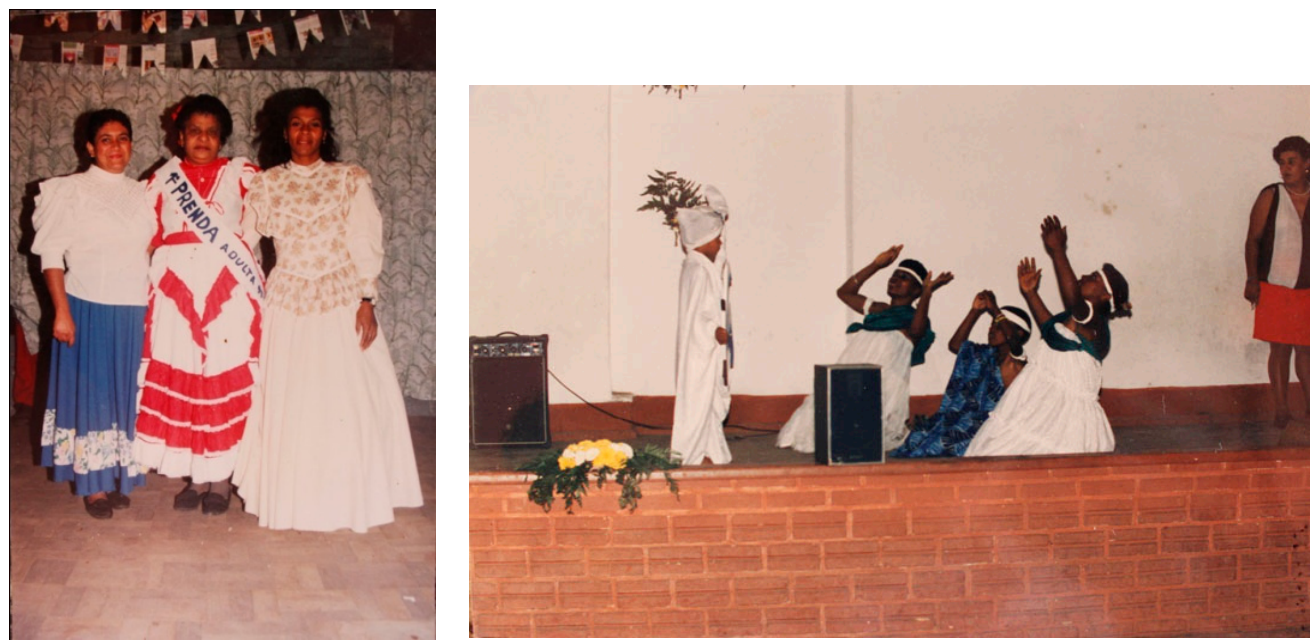

Fotografias do acervo de Leoni

\section{As filhas da água}

O fato de esta intensa atmosfera emocional inscrita na parte de baixo da Ilha da Pintada se desenrolar em uma terreira de Umbanda, e não em uma casa de Batuque, também revela aspectos importantes sobre as relações estabelecidas de forma mais ampla com os moradores da ilha. O antropólogo Norton Correa (1994; 2006), em pesquisa sobre o Batuque no Rio Grande do Sul, aponta para uma distinção entre três vertentes religiosas de matriz africana atuantes no Rio Grande do Sul: a Umbanda pura, o Batuque puro e a Linha Cruzada. De maneira simplificada, poderíamos definir o batuque puro como o culto aos Orixás, que apesar das variações regionais, encontra correspondências com o Candomblé na Bahia e o Xangô Pernambucano. A Umbanda pura estaria associada a uma tríade de influências religiosas católicas, kardecistas e africanas, tentando ao máximo "purificar" e eliminar os componentes afro, como o sacrifício de animais e o toque dos tambores. A Linha Cruzada ocuparia a "zona central do continuum religioso afro-rio-grandense" (Correa, 1994: 33), pois reuniria aspectos da Umbanda e do Batuque, cultuando tanto entidades espirituais (caboclos, preto- 
velhos, ciganas, marinheiros, pomba giras, etc) como orixás. Destas três formas religiosas, prevalecem no Rio Grande do Sul os terreiros de Linha Cruzada, embora a denominação mais usual para tais templos religiosos seja "Centro de Umbanda" ou "Centro Espírita de Umbanda" ${ }^{16}$. A terreira da ilha, o "Centro de Umbanda Reino de Yemanjá e Oxóssi” é claramente um templo de culto da Linha Cruzada, que expressa no próprio nome da casa a relação entre umbanda e o culto aos orixás, em reverência aos dois orixás de cabeça das dirigentes espirituais da casa, respectivamente Bia, filha de Yemanjá, e Leoni, filha de Oxóssi.

O fato de a terreira dirigida por Bia e Leoni se identificar como um Centro de Umbanda merece alguns comentários sobre esta vertente religiosa. A Umbanda é apontada por diversos autores como uma religião autenticamente brasileira, que surge em meados de 1920 com base em um sincretismo negro-católico-espírita que se desenvolve em um movimento simultâneo de empretecimento do espiritismo kardecista e um embranquecimento do candomblé (Ortiz, 1999). A ênfase na missão de promover a caridade e a ajuda, aliada ao acolhimento e reinscrição em uma ordem mítica de figuras marginalizadas na sociedade, como o negro, o índio, a prostituta, o migrante e os pobres em geral fez com que esta forma religiosa sincrética encontrasse um terreno fértil para um amplo desenvolvimento em cidades como Porto Alegre, São Paulo e Rio de Janeiro. Tais cidades, além de possuírem um contingente populacional composto por uma variedade étnica decorrente de levas de migrações que faziam com que o negro, o índio e o branco compartilhassem uma situação de pobreza material, estavam engajadas no processo de modernização da sociedade brasileira que propunha mudanças em suas formas sociais e urbanísticas. Se a Umbanda reflete, no plano religioso, a repercussão das "imposições, contradições e aproximações existentes nas relações entre negros, brancos e índios" (Silva, 2005:129), interessa na interpretação deste caso etnográfico os caminhos ou táticas encontradas pela família de Bia no jogo conflitual que tem lugar nas intersecções dos diferentes territórios da Ilha da Pintada.

A terreira dirigida por Bia, mesmo com sua ênfase nas expressões "afro" de uma negritude gaúcha, não poderia ser uma casa de batuque destinada apenas ao culto

\footnotetext{
${ }^{16} \mathrm{O}$ autor apresenta uma percentagem aproximada do total de casas de culto no Rio Grande do Sul, na qual os templos de Umbanda pura representariam cerca de 5\%; os de Batuque puro, 15\% e os de Linha Cruzada 80\% (CORREA, 1994).
} 
dos orixás. A perdurância da terreira e a adesão ou respeitabilidade adquirida pela liderança de Bia frente aos moradores da ilha faz eco ao rápido desenvolvimento da Umbanda no Brasil, o qual é analisado por vários pesquisadores sob a ótica do embranquecimento do candomblé e consequente minimização de seus componentes "afro" (Ortiz, 1999; Correa, 1994; Silva, 2005), ainda que persista o reconhecimento de um maior axé ou força espiritual das entidades e dirigentes espirituais negros.

As figuras dos caboclos, ciganos, preto-velhos, índios e pomba giras sintetizam estereótipos de grupos marginalizados ou desprestigiados na sociedade que passam a ter uma força simbólica poderosa nos cultos. Tais entidades são ao mesmo tempo possuidoras de força espiritual capazes de socorrer e resolver os problemas das pessoas que os invocam, como são entidades "trabalhadas" e "doutrinadas" para se desenvolverem espiritualmente em outro plano. Quem detém o poder desta doutrinação são os dirigentes espirituais, negros, brancos ou mulatos, que trabalham e conduzem estas entidades. No Centro de Umbanda Reino de Yemanjá e Oxóssi, o poder e o axé negros de Bia e de sua mãe Leoni em receber e doutrinar tais entidades não podem ser destituídos de ênfase. É justamente por ser a Ilha da Pintada conhecida como um território místico da cidade, associado a uma forte religiosidade popular que dá forma às lendas e assombrações que reúnem benzedeiras, bruxas, lobisomens e batuqueiras (Araújo, 1998; Devos, 2007), que a doutrinação das entidades cultuadas na Umbanda é um fator crucial no reconhecimento do axé e da força espiritual desta família negra.

Em um contexto no qual os negros eram constrangidos em praça pública e compreendidos através de um imaginário luso que os associava ao animalesco e ao primitivo, ou ainda, a uma coisa do mal, conforme referido por Bia, sustentar certas práticas rituais características do batuque como o sacrifício de animais, resultaria em maiores dificuldades de diálogo junto a outros segmentos religiosos, como o espiritismo e o catolicismo. Rosi, ao me explicar as diferenças entre umbanda e "nação"17, enfatizava além da ausência do corte, em referência ao sacrifício de animais, o maior número de passagens ${ }^{18}$ que os iniciados possuíam na umbanda:

\footnotetext{
${ }^{17}$ Nação é como também se denomina o Batuque puro no Rio Grande do Sul.

${ }^{18} \mathrm{O}$ termo passagem é usado por praticantes da Umbanda para se referir a uma abertura do corpo aos orixás e entidades que se apropriam temporariamente nos momentos de incorporação.
} 
Rosi: Que a religião é assim, tu tem um pai de cabeça, aquele que manda na tua cabeça, que é o dono da tua cabeça. No caso assim, pra simplificar: eu sou do Xangô, tá, então eu faço toda a minha obrigação pra Xangô, eu tenho Xangô tanto na Nação como na Umbanda, deito pra ele, aí sucessivamente, o meu corpo, que é as minhas passagens, né, eu tenho Oxum, ela também chega, o que é diferente na Nação, que na Nação só chega o pai de cabeça, na Umbanda nós temos que ter 7 passagens. Ai depois eu tenho Preto-Velho, deixa eu ver, que mais...eu tenho Cosme Damião, tenho uma Pomba Gira, tenho um Exu e tenho um Caboclo. Por que? Porque na falta de um, [...] na falta de um, que a gente precisa pra recurso, pra atender alguém, se não tem um, vem o outro, $e,[\ldots]$ vem o outro pra socorrer, né.

Rosi nos mostra a importância de se ter muitas passagens para o caso de ajudar alguém que precise, enfatizando esta característica assistencial da terreira, atraindo e vinculando os moradores do entorno a este lócus religioso de trabalho espiritual e resolução de problemas de diferentes ordens.

Este sincretismo religioso da Umbanda permite que as mesmas santas que circulam por igrejas católicas em datas festivas entrem na terreira para serem homenageadas, como pude presenciar com a imagem de Nossa Senhora Aparecida. A imagem da santa saiu de uma igreja católica na ilha e foi levada até uma tenda improvisada na garagem da casa de uma filha de santo de Bia, local que acolhia as festas maiores da terreira enquanto o salão definitivo não era construído. Lá, recebeu uma homenagem em um ritual de umbanda sem incorporação e com a presença de dirigentes católicos. Ou seja, a terreira participa da circulação espiritual como um ponto de parada no percurso religioso católico na Ilha da Pintada, especialmente nas santas que possuem correspondência com os orixás das águas, como é o caso de Nossa Senhora Aparecida e Nossa Senhora da Conceição, que correspondem a Oxum, e Nossa Senhora dos Navegantes, que corresponde a Yemanjá. Esta entrada das santas na terreira, no entanto, é sempre negociada, ano a ano.

Assim, embora a umbanda minimize as influências africanas para se consolidar como uma religião "autenticamente brasileira", a influência africana que "sai" do rito sendo "purificada" no contexto umbandista, é reinscrita na valorização das expressões culturais por esta família negra, aquilo que é bem visto e valorizado pela sociedade mais ampla, especialmente em um contexto atual de políticas afirmativas. A "negritude" não está no sacrifício de animais ou em uma dança de incorporação, mas na realização de 
casamentos afro, na persistência de uma escola de samba que todos os anos desfila sob os olhares receosos dos moradores de cima, no domínio da dança e dos tambores.

Como mostra o antropólogo Vagner Gonçalves da Silva (2005), o surgimento da Umbanda também torna mais explícitas e visíveis as relações entre políticos e religiosos, na medida em que o "embranquecimento" da matriz africana torna suas expressões religiosas mais digeríveis à opinião pública. Bia, em sua "liderança carismática", ultrapassa a dimensão religiosa entrelaçando-a com diretrizes políticas. A liderança de Bia era fundamental na manutenção de boas relações com diferentes lideranças e moradores da Ilha, como por exemplo, com os padres católicos, com representantes dos pescadores e da Colônia de Pescadores Z5, com lideranças comunitárias, com professores e diretores das escolas, entre outros. É assim que a terreira se firma como um lócus religioso, cultural e político que transita com habilidade entre diferentes pertenças étnicas e religiosas, promovendo ajuda à comunidade de entorno e sempre enfatizando a adesão e o pertencimento à Ilha da Pintada.

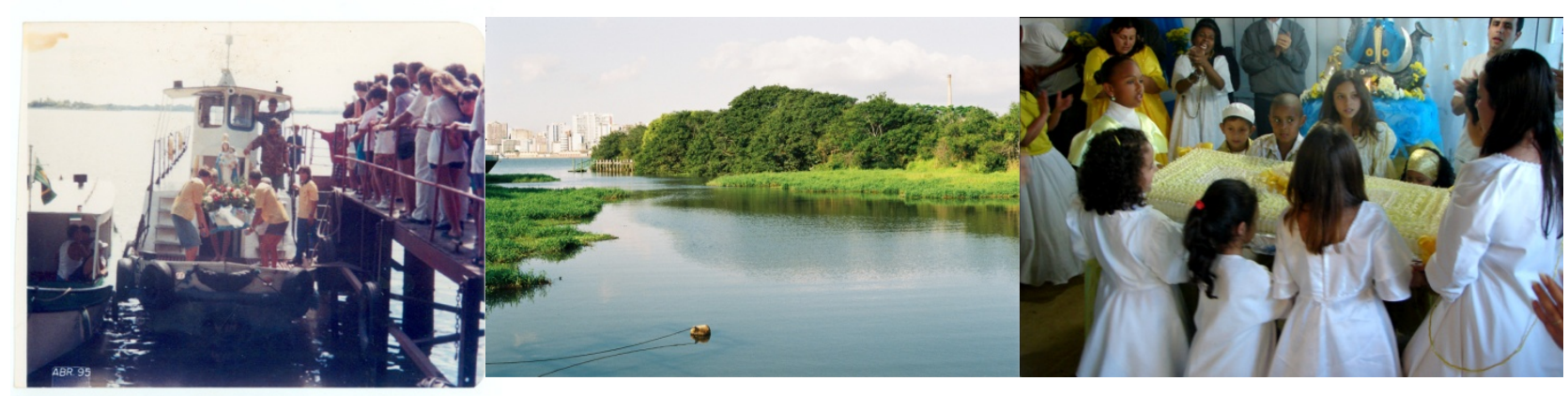

Fotografias da autora e do acervo de Eliane

Com características de um "santuário natural", a ilha possui um grande contato com o fluxo das águas doces, que atravessam o delta em direção ao mar. As ilhas do delta tanto recebem a água das nascentes e cachoeiras que é própria de Oxum, como encaminham esta mesma água que então compõe o lago Guaíba a desaguar na Lagoa dos Patos e finalmente, nas águas salgadas do mar, a morada de Yemanjá. Esta proximidade em uma casa de culto cujos filhos de santo são predominantemente "filhos 
da água", dos orixás Oxum e Yemanjá, é uma vantagem que inscreve um maior axé ${ }^{19}$ aos praticantes e à imagem da terreira ${ }^{20}$.

Este traço distintivo do Centro de Umbanda Reino de Yemanjá e Oxóssi em acolher principalmente "filhas da água" consistia em um modo de imprimir certa tonalidade à terreira, como me relatou uma filha de santo de Bia, diante de minha indagação acerca da ausência, na terreira, de filhas de outros orixás femininos, como Iansã:

Iansã, orixá valente e guerreira, rainha dos ventos e tempestades, conhecedora dos mistérios dos raios, imprime uma personalidade impetuosa, sensual e colérica a seus filhos, qualidades psicológicas femininas pouco apreciadas em contextos onde se faz necessário um controle moral específico. Assim, na terreira, as mulheres de Iansã, passavam a trabalhar para Oxum, acalmando os aspectos mais turbulentos de sua personalidade e investindo nas qualidades de sua nova mãe espiritual.

Ao discutir indivíduo e religião na cultura brasileira, o antropólogo Gilberto Velho (2003) chama a atenção para o fato de que as personalidades ou perfis psicológicos evocam uma forte conotação e ênfase morais, onde ser sério, honesto, trabalhador e instruído são qualidades muito valorizadas em certas vertentes religiosas. Na Ilha da Pintada, estas qualidades também preservam relações de vizinhança em um contexto onde ser negro representa uma coisa do mal, e cultuar a umbanda era ser filho do demônio. Ou seja, para além de uma convivência religiosa sempre conflitual, ser negro e batuqueiro ou umbandista já operava em um registro de desvantagem diante dos demais pertencimentos étnicos e religiosos, sendo necessária uma reversão do estigma das religiões de matriz africana, interpretadas como "atávicas", "primitivas" e "violentas".

A domesticação do "sagrado selvagem" das "filhas da água", as quais produziam uma atmosfera calma desejável à terreira para que esta conquistasse um estatuto de respeitabilidade frente aos segmentos religiosos mais tradicionais na Ilha da Pintada, em especial, o catolicismo.

\footnotetext{
${ }^{19} \mathrm{O}$ axé, nos cultos afro-brasileiros representa a força vital e espiritual, podendo ser compreendido como uma espécie de mana, nos termos de Marcel Mauss (2003).

${ }^{20} \mathrm{O}$ antropólogo Rafael Devos (2007), interessado nos diferentes usos e significados da água entre os moradores das ilhas que integram o Delta do Jacuí, no contexto urbano da cidade de Porto Alegre, coletou depoimentos de Bia sobre o axé das águas, identificando a proximidade das águas no contexto afroreligioso como um privilégio associado à uma dimensão espiritual no jogo conflitual que mobiliza interesses variados nos usos deste ambiente natural.

${ }^{21}$ Cf Roger Bastide, (2006).
} 


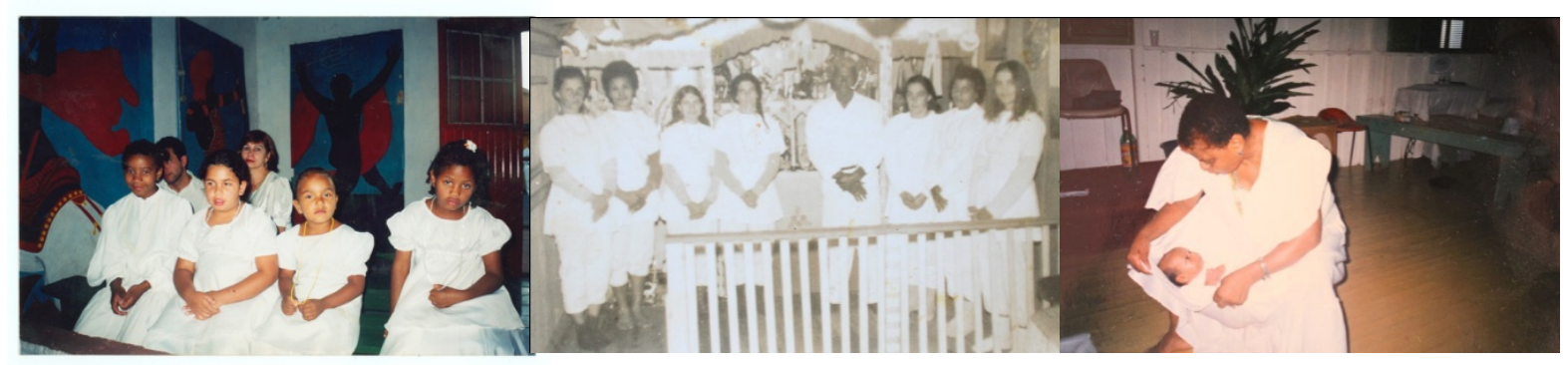

Fotografias do acervo de Eliane e Leoni

A intensidade e o investimento em torno de todas estas práticas mostram um esforço contínuo do grupo em fazer "durar" uma memória do negro na ilha, nos contornos de uma duração "vivida, sentida, amada, cantada, romanceada" (Bachelard, 1994:104), e narrada nas memórias dos mais velhos, na Umbanda, no carnaval, nos tambores, no maculelê. $\mathrm{O}$ aprendizado dessas práticas e tradições, por parte dos mais jovens, organiza uma continuidade das tradições, sempre atualizadas, como Leoni nos chama atenção ao narrar as diferenças da religião no tempo em que os tambores soavam baixinho. Em certa medida, trata-se também da "transmissão de padrões distintivos" (Elias e Scotson, 2000: 169) às novas gerações, em que as crianças são iniciadas em aptidões específicas e desde muito pequenas assumem um lugar social na família, no grupo, e no território mais amplo da Ilha da Pintada.

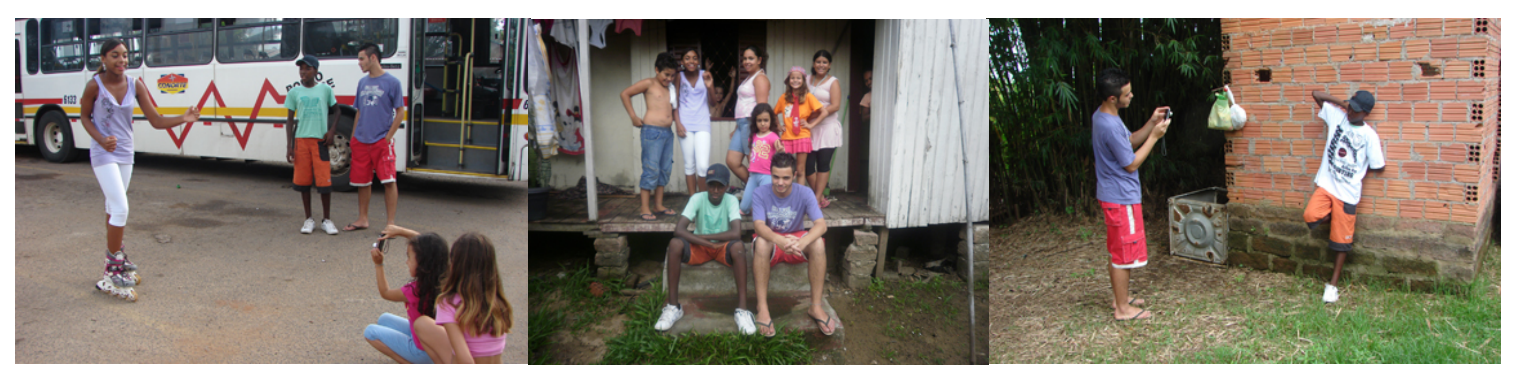

Fotografias da autora

Os jovens, embora afirmassem sentir preconceito na escola e em outras localidades da ilha pela cor, religiosidade, profissão, local de moradia e "cultura", estavam amparados e envolvidos no ambiente proxêmico da terreira, vinculados às entidades e guias espirituais. Ao compartilharem a escuta das experiências das gerações antecessoras, como de Bia e Leoni, eles pareciam mais preparados para lidar com as diferentes formas de preconceito. A construção da autoimagem destes jovens, portanto, 
acontecia de uma forma e em um contexto muito diferente do que as gerações anteriores. Ainda que a volta por cima, não seja uma conquista perene, estando sempre sujeita às oscilações psicossociais que definem os sujeitos da margem, vemos a eficácia das táticas dessa rede de moradores na trajetória de alguns desses jovens cujas escolhas de vida aproximam arte, religiosidade e afirmação étnica.

\section{REFERÊNCIAS}

ARAÚJO, Susana de Azevedo. Bruxas e bruxarias na Ilha da Pintada, Porto Alegre, $R S$. Dissertação de Mestrado. Universidade Federal do Rio Grande do Sul, Instituto de Filosofia e Ciências Humanas, Programa de Pós-Graduação em Antropologia Social, 1998.

BACHELARD, Gaston. A Poética do Espaço. São Paulo: Martins Fontes, 1996.

. A Dialética da Duração. São Paulo: Ática, 1994.

BARTH, Fredrik. "Grupos Étnicos e suas Fronteiras." In: POUTIGNAT, Phillippe; STREIFF-FENART, Jocelyne. Teorias da Etnicidade. São Paulo: UNESP, 1998.

BASTIDE, Roger. "O sagrado selvagem” [1973]. In: . O sagrado selvagem $e$ outros ensaios. São Paulo: Companhia das Letras, 2006, pp. 250-275.

BITTENCOURT, Iosvaldyr Carvalho. "A esquina do Zaire: territorialidade negra urbana em Porto Alegre". In: LEITE, Ilka Boaventura. Negros no Sul do Brasil: invisibilidade e territorialidade. Florianópolis: Letras Contemporâneas, 1996.

BOTT, Elizabeth. Familia e rede social. Rio de Janeiro: Francisco Alves, 1976.

BUCCI, Eugenio. "Meu pai, meus irmãos e o tempo".

In: MAMMI, L.; SCHWARCZ, L. $8 x$ fotografia: ensaios. São Paulo: Companhia das Letras, 2008.

CERTEAU, Michel de. A invenção do cotidiano: artes de fazer. $4^{\mathrm{a}}$ edição. Petrópolis, RJ: Vozes, 1994 [1990].

CERTEAU, Michel de; GIARD, Luce; MAYOL, Pierre. A invenção do cotidiano. Vol 2. Morar, cozinhar. Petrópolis: Vozes, 1996.

CORREA, Norton Figueiredo. O Batuque do Rio Grande do Sul. 2a edição. Porto Alegre: Editora da Universidade, 2006. 
. "Panorama das religiões afro-brasileiras do Rio Grande do Sul". In: ORO, Ari Pedro (org.). As religiões afro-brasileiras do Rio Grande do Sul. Porto Alegre: Editora da Universidade/UFRGS, 1994, pp.09-46.

DAMATTA, Roberto. Carnavais, malandros e heróis: para uma sociologia do dilema

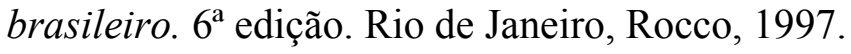

DÁVILA, Jerry. Diploma de brancura. Política social e racial no Brasil - 1917 - 1945. São Paulo: Editora UNESP, 2006.

DEVOS, Rafael Victorino. A "questão ambiental" sob a ótica da antropologia dos grupos urbanos, nas ilhas do Parque Estadual Delta do Jacuí, Bairro Arquipélago, Porto Alegre, RS. Tese de Doutorado. Universidade Federal do Rio Grande do Sul, Instituto de Filosofia e Ciências Humanas, Programa de Pós-Graduação em Antropologia Social, 2007.

DURAND, Gilbert. "O imaginário e o funcionamento social da marginalização". Campos do Imaginário. Lisboa: Instituto Piaget, 1998b.

ECKERT, Cornelia. Os homens da mina: um estudo das condições de vida e representações dos mineiros de carvão em Charqueadas - RS. Dissertação de Mestrado. Programa de Pós Graduação em Antropologia Social, UFRGS, 1985.

ECKERT, Cornelia; ROCHA, Ana Luiza Carvalho da. O tempo e a cidade. Porto Alegre: Editora da Universidade, 2005.

ELIAS, Norbert; SCOTSON, John L. Os estabelecidos e os outsiders. Tradução de Vera Ribeiro. Rio de Janeiro: Jorge Zahar Editor, 2000.

GOFFMAN, Erving. Estigma. Notas sobre a Manipulação da Identidade Deteriorada. $4^{a}$ edição. Rio de Janeiro: Zahar Editores, 1982.

LÓPEZ, Laura Cecilia. "Que America Latina se sincere”: Uma análise antropológica das políticas e poéticas do ativismo negro em face às ações afirmativas e às reparações no Cone Sul. Tese de Doutorado. Universidade Federal do Rio Grande do Sul, Instituto de Filosofia e Ciências Humanas, Programa de Pós-Graduação em Antropologia Social, 2009.

MEYER, Augusto. Cancioneiro Gaúcho. Porto Alegre: Editora Globo, 1959.

MONTEIRO, Charles. Porto Alegre e suas escritas: história e memórias da cidade. Porto Alegre: Edipucrs, 2006.

NUNES, Margarete F.; ROCHA, Ana Luiza C. "Etnografando narrativas étnicas no espaço da cidade: os negros e as ações afirmativas na sociedade brasileira contemporânea”. Revista Eletrônica Iluminuras, vol. 10, n. 23, 2009.

ORTIZ, Renato. A morte branca do feiticeiro negro. Umbanda e Sociedade Brasileira. $2^{\mathrm{a}}$ edição. São Paulo: Brasiliense, 1999. 
OLIVEN, Ruben George. A parte e o todo: a diversidade cultural no Brasil-nação. $2^{\mathrm{a}}$ edição. Petrópolis: Vozes, 2006.

- A invisibilidade social e simbólica do negro no Rio Grande do Sul. In: LEITE, Ilka Boaventura. Negros no Sul do Brasil: invisibilidade e territorialidade. Florianópolis: Letras Contemporâneas, 1996.

PARK, Robert Ezra. "A cidade: sugestões para a investigação do comportamento humano no meio urbano". In: VELHO, Otávio G. (org). O Fenômeno Urbano. $4^{\mathrm{a}}$ edição. Rio de Janeiro: Editora Guanabara, 1987, pp. 26-67.

POLLAK, Michael. Memória, Esquecimento, Silêncio. Estudos Históricos, Rio de Janeiro, vol. 2, n. 3, 1989, pp. 3-15.

PORTO ALEGRE, Secretaria Municipal da Cultura, Centro de Pesquisa Histórica. Arquipélago: as ilhas de Porto Alegre. GOMES, José Juvenal; MACHADO, Helena Vitória dos Santos; VENTIMIGLIA, Marise Antunes. Porto Alegre: Unidade Editorial, 1995.

SILVA, Vagner Gonçalves da. Candomblé e Umbanda. Caminhos da devoção brasileira. $2^{\mathrm{a}}$ edição. São Paulo: Selo Negro, 2005.

SIMMEL, Georg. A natureza sociológica do conflito. In: FILHO, Evaristo de Moraes (org). Simmel. São Paulo: Ática, 1983.

VELHO, Gilberto. Individualismo e Cultura. Notas para uma Antropologia das Sociedade Contemporânea. $8^{\text {a }}$ edição. Rio de Janeiro: Jorge Zahar, 2008.

Projeto e metamorfose. Antropologia das Sociedades Complexas. $3^{\text {a }}$ edição. Rio de Janeiro: Jorge Zahar Editor, 2003 [1994].

Recebido: $31 / 01 / 2020$

Aprovado: $15 / 07 / 2020$ 